\title{
TERAPI GIZI MEDIS PADA DIABETES MELITUS
}

\author{
Franky A. Tumiwa \\ Yuanita A. Langi
}

\author{
Divisi Endokrin Metabolik Bagian Ilmu Penyakit Dalam \\ Fakultas Kedokteran Universitas Sam Ratulangi Manado \\ Email: anq23wa@yahoo.com
}

\begin{abstract}
Asbtract: Medical nutrition therapy is a vital component in managing diabetes which aims to prevent the progression of chronic complications of diabetes by modification in nutrient intake and lifestyle. Medical nutrition therapy for people with diabetes should be individualized, with consideration given to the individual's usual food, eating habits, metabolism, physical activity, and co-morbid conditions. Medical nutrition therapy in special conditions such as acute illness, hypoglycemia, old age, pregnancy, lactation, hypertension, nephropathy, and dyslipidemia should be managed carefully.
\end{abstract}

Keywords: Medical nutrition therapy, diabetes, individual, complication

\begin{abstract}
Abstrak: Terapi gizi medis merupakan komponen penting dalam pilar penatalaksanaan diabetes yang bertujuan untuk mencegah dan memperlambat laju perkembangan komplikasi kronis dari diabetes dengan memodifikasi asupan gizi dan gaya hidup. Pada setiap penyandang diabetes, terapi gizi medis bersifat individual sebab harus mempertimbangkan kebiasaan makan setempat, metabolisme, aktivitas fisik, dan adanya komorbid. Terapi gizi medis pada penyandang diabetes dengan keadaan khusus, seperti penyakit akut, hipoglikemia, perawatan medis, lanjut usia, kehamilan, laktasi, hipertensi, nefropati dan dislipidemia, amat penting dilaksanakan sebab menentukan keberhasilan terapi.
\end{abstract}

Kata kunci: Terapi gizi medis, diabetes, individu, komplikasi

Terapi gizi medis (TGM) adalah terapi gizi yang meliputi terapi diagnostik, dan manajemen penyakit termasuk layanan konseling, yang diberikan oleh seorang ahli diet terdaftar (registered dietitian) atau seorang ahli gizi profesional (nutrition professional). ${ }^{1}$

Terapi gizi medis pada penyandang prediabetes atau diabetes bertujuan untuk pencegahan diabetes, mengelola individu yang sudah menderita diabetes, serta mencegah atau memperlambat perkembangan komplikasi diabetes. ${ }^{1,2}$

The American Diabetes Association (ADA) 2009 menyatakan bahwa penyandang prediabetes atau diabetes harus mendapatkan terapi gizi medis secara individual untuk mencapai tujuan perawatan. ${ }^{1}$

Berdasarkan hasil uji klinis dari terapi gizi medis, dilaporkan adanya penurunan HbA1c (A1C) sebanyak 1\% pada diabetes tipe 1 dan $1-2 \%$ pada diabetes tipe 2, serta berdasarkan studi meta-analisis pada individu nondiabetes, terapi gizi medis dapat mengurangi kolesterol LDL sebanyak 15-25 $\mathrm{mg} / \mathrm{dL}$ dimana perbaikan dapat terlihat dalam 3-6 bulan sejak dimulainya terapi. ${ }^{3}$

Dalam artikel ini akan dibahas mengenai tujuan dari terapi gizi medis, efektivitas, keseimbangan energi dan berat badan, komposisi makro nutrient dan mikro nutrien dari diet pada penyandang diabetes, rekomendasi gizi dan intervensi dalam pencegahan diabetes primer, sekunder dan tersier serta pada komplikasi akut, dan juga pada keadaan penyandang diabetes dengan penyakit komorbid. 


\section{TUJUAN TERAPI GIZI MEDIS}

Tujuan dari TGM adalah untuk mencapai dan memelihara kadar glukosa darah dalam batas normal atau mendekati normal seaman mungkin, mencapai dan memelihara kadar profil lipid dan lipoprotein untuk mengurangi risiko penyakit vaskular, serta mempertahankan tekanan darah dalam batas normal atau mendekati normal seaman mungkin. ${ }^{1}$

Terapi gizi medis juga bertujuan untuk mencegah, memperlambat laju perkembangan komplikasi kronis dari diabetes dengan memodifikasi asupan zat gizi, gaya hidup, dan untuk memenuhi kebutuhan gizi individu, dengan tetap mempertimbangkan preferensi pribadi atau kebiasaan budaya setempat, serta mempertahankan kenikmatan dalam mengonsumsi makanan. ${ }^{1,2}$

\section{EFEKTIVITAS TERAPI GIZI MEDIS}

Berdasarkan hasil penelitian dan uji klinis dari TGM telah dilaporkan adanya penurunan HbA1c (A1C) sebanyak 1\% pada diabetes tipe 1 dan $1-2 \%$ pada diabetes tipe 2. Beberapa studi meta-analisis pada indivi$\mathrm{du}$ yang nondiabetes, penerapan TGM terbukti mengurangi kolesterol LDL sebanyak $15-25 \mathrm{mg} / \mathrm{dL}$ dimana perbaikan mulai terlihat dalam 3-6 bulan terapi. ${ }^{3,4}$

Terapi gizi medis dapat dipertimbangkan sebagai monoterapi atau secara bersama dengan aktivitas fisik, dalam pengobatan awal suatu diabetes tipe 2 bilamana kadar glukosa plasma puasa $<200 \mathrm{mg} / \mathrm{dL}$. Individu dengan diabetes tipe 2 yang tidak dapat mencapai kontrol optimal dengan TGM, maka perlu dipertimbangkan pemberian terapi farmakologis dalam mengontrol kadar glukosa plasma. ${ }^{4}$

\section{KESEIMBANGAN ENERGI DAN BE- RAT BADAN}

Obesitas telah diakui sebagai penyebab utama resistensi insulin yang mencetuskan terjadinya diabetes tipe 2 , sehingga kontrol terhadap berat badan sangat penting untuk penyandang diabetes atau berisiko untuk diabetes. 5 Studi menunjukkan bahwa sedikitnya $80 \%$ dari yang baru didiagnosis dengan diabetes tipe 2 mengalami kelebihan berat badan. Penurunan berat badan pada penyandang diabetes tipe 2 dengan berat badan lebih, dapat meningkatkan angka harapan hidup. ${ }^{5}$

The National Heart, Lung and Blood Institute $^{5}$, menyatakan bahwa yang termasuk pada kategori berat badan lebih (overweight) adalah individu dengan indeks massa tubuh (IMT) $\geq 25 \mathrm{~kg} / \mathrm{m} 2$, sedangkan yang tergolong obesitas adalah dengan IMT $\geq 30 \mathrm{~kg} / \mathrm{m}^{2}$ (Tabel 1). Adanya peningkatan risiko penyakit komorbid yang berhubungan dengan kelebihan lemak viseral, dapat diukur melalui lingkar pinggang yaitu $\geq 100 \mathrm{~cm}$ pada laki-laki, dan $\geq 90 \mathrm{~cm}$ pada perempuan, sedangkan khusus untuk Asia adalah $\geq 90$ $\mathrm{cm}$ pada laki-laki dan $\geq 80 \mathrm{~cm}$ pada perempuan.

Strategi pengaturan kalori untuk manajemen berat badan harus didasarkan pada bobot target realistis. ${ }^{5}$ Penilaian bobot tersebut adalah menurut tingkat energi dan aktivitas masing-masing individu sehingga dibutuhkan suatu rumusan untuk memperkirakan tingkat metabolisme basal dan pengeluaran energi setiap hari berdasarkan berat badan dan aktivitas seperti pada Tabel 2 . $^{2}$

Bukti menunjukkan bahwa dengan mengurangi energi dan asupan lemak $( \pm 30 \%$ dari energi total), aktivitas fisik reguler, dapat menghasilkan penurunan berat badan 5 - 7\% dari berat awal. ${ }^{4}$ Diet standar dalam menurunkan berat badan adalah dengan mengurangi asupan 500-1000 kalori per hari ternyata dapat menurunkan berat badan 0,5-1 $\mathrm{kg} /$ minggu. 4

\section{KOMPOSISI MAKRONUTRIEN}

Komponen-komponen gizi yang termasuk dalam makronutrien adalah karbohidrat, protein dan lemak. Komposisi makronutrien yang direkomendasi pada pasien diabetes adalah karbohidrat $45-60 \%$, protein $10-$ $20 \%$, Cis-monounsaturated fat 10-20\%, polyunsaturated fat $5-10 \%$ dan saturated trans fat 5-10\%. ${ }^{1}$

Pada terapi gizi medis, jenis karbohidrat dibagi berdasarkan indeks glisemik (IG)/ glycemic index (GI), yaitu suatu indeks makanan berdasarkan efek langsung pada 
Tabel 1. Klasifikasi dari overweight dan obesitas berdasarkan IMT, ukuran lingkar pinggang dan dihubungkan dengan risiko penyakit komorbid

\begin{tabular}{|c|c|c|c|c|}
\hline & \multirow[b]{2}{*}{$\begin{array}{l}\text { IMT } \\
\left(\mathrm{kg} / \mathrm{m}^{2}\right)\end{array}$} & \multirow[b]{2}{*}{$\begin{array}{l}\text { Tingkat } \\
\text { obesitas }\end{array}$} & \multicolumn{2}{|c|}{ Resiko sakit $^{*}$} \\
\hline & & & $\begin{aligned} \text { LP pria } & \leq 40 \text { inci, } \\
\text { wanita } & \leq 35 \text { inci }\end{aligned}$ & $\begin{array}{r}\text { LP pria } \geq 40 \text { inci, } \\
\text { wanita } \geq 35 \text { inci }\end{array}$ \\
\hline BB kurang & $<18,5$ & & & \\
\hline Normal & $18,5-24,9$ & & & \\
\hline BB berlebih & $25,0-29,9$ & & Meningkat & Tinggi \\
\hline Obesitas & $30,0-34,9$ & I & Tinggi & Sangat tinggi \\
\hline & $35,0-39,9$ & II & Sangat tinggi & Sangat tinggi \\
\hline Obesitas berat & $\geq 40$ & III & Amat sangat tinggi & Amat sangat tinggi \\
\hline
\end{tabular}

Sumber: Bantle, Wylie-Rosett et al, 2008

Tabel 2. Tingkat metabolisme basal dan pengeluaran energi setiap hari menurut berat badan dan aktivitas fisik

\begin{tabular}{|c|c|c|c|}
\hline $\begin{array}{l}\text { Rentang } \\
\text { usia (thn) }\end{array}$ & $\begin{array}{c}\text { BMR } \\
\text { (kkal/hari) }\end{array}$ & $\begin{array}{r}\text { Tingkat } \\
\text { aktivitas }\end{array}$ & $\begin{array}{l}\text { Penggunaan energi } \\
24 \text { jam (kkal/hari) }\end{array}$ \\
\hline \multicolumn{4}{|l|}{ Pria } \\
\hline $10-18$ & $17,5 \mathrm{~W}+651$ & Inaktif & BMR $x 1,30$ \\
\hline $18-30$ & $15,3 W+679$ & Ringan & BMR $x 1,55$ \\
\hline $30-60$ & $11,6 \mathrm{~W}+879$ & Sedang & BMR $x 1,78$ \\
\hline$>60$ & $13,5 \mathrm{~W}+487$ & Berat & BMR $\times 2,10$ \\
\hline \multicolumn{4}{|l|}{ Wanita } \\
\hline $10-18$ & $12,2 \mathrm{~W}+746$ & Inaktif & BMR x 1,30 \\
\hline $18-30$ & $14,7 W+496$ & Ringan & BMR $x 1,56$ \\
\hline $30-60$ & $8,7 \mathrm{~W}+829$ & Sedang & BMR $x 1,64$ \\
\hline$>60$ & $10,5 W+596$ & Berat & BMR $x 1,82$ \\
\hline
\end{tabular}

Sumber : McGough, 2007

Tabel 3. Klasifikasi karbohidrat berdasarkan indeks glisemik

\begin{tabular}{|l|l|l|}
\hline \multicolumn{1}{c|}{ Classification } & \multicolumn{1}{c}{ GI range } & \multicolumn{1}{c}{ Examples } \\
\hline Low GI & 55 or less & $\begin{array}{l}\text { most fruits and vegetables (except potatoes and } \\
\text { watermelon), whole-grain breads, pasta, legumes/ } \\
\text { pulses, milk, yogurt, products extremely low in } \\
\text { carbohydrates (some cheeses, nuts), fructose }\end{array}$ \\
\hline Medium GI & $56-69$ & $\begin{array}{l}\text { whole wheat products, basmati rice, sweet potato, } \\
\text { table sugar }\end{array}$ \\
\hline High GI & 70 and above & $\begin{array}{l}\text { corn flakes, rice krispies, baked potatoes, water- } \\
\text { melon, croissants, white bread, extruded breakfast } \\
\text { cereals, most white rices, straight glucose (100) }\end{array}$ \\
\hline
\end{tabular}

Sumber: Holt SHA, Miller JC, 2007.

kadar glukosa darah terhadap waktu (Tabel $3)^{6}$ Indeks glisemik makanan didefinisikan sebagai luas daerah di bawah dua jam pada kurva respon glukosa darah setelah konsumsi 50 gr karbohidrat. Pada sembilan studi tentang pengaruh dari indeks glisemik pada pasien diabetes, didapatkan bahwa dengan mengkonsumsi karbohidrat yang rendah indeks glisemik (nilai IG <55\%) dapat mengurangi konsentrasi HbA1c sebanyak $0,4 \%$ dibandingkan mengkonsumsi karbohidrat yang tinggi indeks glisemik selama 


\section{2 minggu. $^{7}$}

Komposisi protein pada diet yang dianjurkan adalah 10-20\% dari total asupan energi, dengan angka kebutuhan harian adalah $0,8 \mathrm{gr} / \mathrm{kg}$ berat badan yang berasal dari sumber protein berkualitas baik (protein yang dapat dicerna dan mengandung sembilan jenis asam amino esensial). Contohnya adalah daging, unggas, ikan, telur, susu, keju, dan kedelai. Sumber protein yang tidak dalam kategori "baik" misalnya sereal, bijibijian, kacang-kacangan, dan sayuran. ${ }^{1}$

Asupan protein bagi individu dengan diabetes adalah sama dengan masyarakat umum dan biasanya tidak melebihi $20 \%$ dari asupan energi. Sejumlah penelitian pada orang sehat dan pada penyandang diabetes tipe 2 menunjukkan bahwa glukosa yang berasal dari protein yang dicerna tidak meningkatkan konsentrasi plasma glukosa tetapi menyebabkan peningkatan respon insulin serum. ${ }^{4}$ Pada suatu studi menunjukkan bahwa diet dengan kandungan protein $>20 \%$ dari total energi dapat mengurangi konsentrasi glukosa dan insulin, mengurangi nafsu makan, serta meningkatkan perasaan cepat kenyang, akan tetapi efek dari diet tinggi protein dalam jangka waktu yang lama belum dapat diketahui secara pasti. ${ }^{4,8}$

Tujuan pengaturan diet lemak pada penyandang diabetes adalah untuk membatasi asam lemak jenuh, asam lemak trans, dan asupan kolesterol sehingga mengurangi risiko penyakit kardiovaskuler. ${ }^{8}$ Asam lemak jenuh dan asam lemak trans merupakan penentu utama kadar kolesterol LDL plasma. Pada individu nondiabetes, dengan mengurangi asam lemak jenuh dan asam lemak trans akan menurunkan kolesterol total dan LDL. ${ }^{8}$

Manajemen diet untuk penyandang diabetes adalah sama untuk penyandang penyakit kardiovaskuler sebab kedua kelompok ini memiliki risiko yang setara, sehingga direkomendasikan asupan asam lemak jenuh yang $<7 \%$ dari energi total harian, seminimal mungkin asupan asam lemak trans, dan asupan kolesterol harian $<200 \mathrm{mg} .{ }^{4,8}$

Konsumsi asam lemak omega-3 dari ikan atau dari suplemen telah terbukti mengurangi risiko penyakit kardiovaskuler, sehingga dua atau lebih porsi ikan per minggu dapat dire- komendasikan. ${ }^{4}$

\section{KOMPOSISI MIKRONUTRIEN}

Tidak terdapat bukti yang jelas tentang manfaat dari suplemen vitamin atau mineral pada orang dengan diabetes (dibandingkan dengan populasi umum) yang tidak memiliki defisiensi vitamin atau mineral yang mendasar. ${ }^{4}$ Pemberian suplemen rutin dengan antioksidan seperti vitamin $\mathrm{E}$, vitamin $\mathrm{C}$ dan karoten, tidak disarankan karena kurangnya bukti keberhasilan dan hubungan yang jelas dengan efek samping pemakaian jangka panjang. ${ }^{9}$ Beberapa studi klinis kecil yang melibatkan penyandang diabetes yang diberikan makanan tertentu yang memiliki potensi antioksidan tinggi (misalnya, teh, kakao, kopi) memberikan hasil yang tidak memuaskan. ${ }^{9}$ Data percobaan klinis tidak hanya menunjukkan kurangnya manfaat terhadap kontrol glisemik dan perkembangan komplikasi tetapi juga memberikan bukti potensi kerugian dari pemberian vitamin E, karoten, dan suplemen antioksidan lainnya. ${ }^{9}$ Selain itu, data yang tersedia tidak mendukung penggunaan suplemen antioksidan dalam mengurangi risiko penyakit kardiovaskuler, sehingga penggunaan suplemen secara farmakologis tidak disarankan. Konsumsi makanan yang kaya bahan alami dan mengandung antioksidan dalam jumlah yang bermakna, terutama buah dan sayuran adalah sumber vitamin serta antioksidan yang direkomendasikan. ${ }^{10}$

\section{REKOMENDASI NUTRISI UNTUK DIABETES}

Rekomendasi nutrisi pada diabetes mencakup rekomendasi untuk pencegahan diabetes primer, pengendalian diabetes (pencegahan diabetes sekunder), pengendalian komplikasi diabetes (pencegahan diabetes tersier), diabetes dengan komplikasi akut, dan untuk penyandang diabetes dengan keadaan khusus.

\section{Rekomendasi nutrisi untuk pencegahan diabetes primer}

Pada individu yang berisiko tinggi untuk 
diabetes tipe 2, program terstruktur yang menekankan pada perubahan gaya hidup yakni mencakup penurunan berat badan $(7 \%$ dari total berat badan) dan aktivitas fisik secara teratur (150 menit / minggu), dengan strategi diet termasuk mengurangi kalori dan asupan lemak, dapat mengurangi risiko diabetes. $^{4,11}$

Individu yang berisiko tinggi untuk diabetes tipe 2 harus dianjurkan untuk diet tinggi serat (14 g serat / $1000 \mathrm{kkal})$ dan makanan biji-bijian yang masih mengandung kulit utuh (whole grains). ${ }^{11}$

Belum terdapat cukup informasi yang konsisten untuk menyimpulkan bahwa makanan dengan indeks glisemik rendah dapat mengurangi risiko diabetes; namun demikian, tetap dianjurkan untuk mengkonsumsi makanan dengan indeks glikemik rendah yang kaya serat dan nutrisi penting lainnya. ${ }^{12}$

Beberapa studi observasional melaporkan bahwa konsumsi alkohol dalam jumlah sedang (14-45 gr alkohol per hari) dapat mengurangi risiko untuk diabetes juga penyakit kardiovaskuler, namun data-data tersebut tidak mendukung dalam menganjurkan konsumsi alkohol kepada individu-individu dengan risiko diabetes. ${ }^{13}$

\section{Rekomendasi nutrisi untuk pengendalian diabetes (Pencegahan diabetes sekunder) Pengaturan karbohidrat}

Pola diet yang mencakup karbohidrat dari buah-buahan, sayuran, biji-bijian, kacangkacangan, dan susu rendah lemak dianjurkan dalam terapi gizi pasien diabetes. ${ }^{4}$ Mengatur jumlah karbohidrat, berupa total kalori, pertukaran jenis karbohidrat atau estimasi berbasis pengalaman, tetap menjadi strategi utama dalam mencapai kontrol glikemia. ${ }^{4,11}$

Pengetahuan tentang penggunaan indeks glisemik dapat memberikan manfaat tambahan dalam mengatur jumlah karbohidrat yang akan dikonsumsi. ${ }^{11}$

Makanan yang mengandung sukrosa dapat menggantikan karbohidrat lain dalam pengaturan diet, atau jika ditambahkan ke dalam diet maka haruslah disesuaikan dengan jumlah insulin yang akan digunakan atau penggunaan obat anti diabetik lainnya.
Hal ini perlu diperhatikan dengan baik guna menghindari kelebihan asupan energi. ${ }^{11}$

Penyandang diabetes dianjurkan untuk mengkonsumsi berbagai makanan yang mengandung serat; namun, masih kurangnya bukti ilmiah yang merekomendasikan bahwa penyandang diabetes dianjurkan untuk mengkonsumsi serat yang lebih banyak daripada populasi secara keseluruhan. ${ }^{4}$

Pemanis alkohol non gizi adalah aman jika dikonsumsi dalam tingkat asupan harian yang ditetapkan oleh FDA. ${ }^{14}$

\section{Pengaturan lemak dan kolesterol}

Pengaturan diet lemak makanan pada penyandang diabetes adalah dengan membatasi konsumsi asam lemak jenuh, asam lemak trans, dan asupan kolesterol sehingga mengurangi risiko penyakit kardiovaskuler sebab ketiganya merupakan komponen diet yang merupakan penentu kadar kolesterol LDL plasma. ${ }^{4}$

Berdasarkan beberapa penelitian tentang diet asam lemak jenuh dan asam lemak trans pada penyandang diabetes, disimpulkan bahwa konsumsi asam lemak jenuh yang direkomendasikan adalah $<7 \%$ dari energi total, konsumsi asam lemak trans yang seminimal mungkin, dan asupan kolesterol $<200$ $\mathrm{mg} /$ hari. ${ }^{4}$

Konsumsi asam lemak omega-3 yang berasal dari ikan atau dari suplemen, terbukti dapat menurunkan risiko kejadian kardiovaskuler, sehingga dianjurkan penyandang diabetes untuk mengkonsumsi ikan segar sebanyak dua atau tiga kali per minggu. ${ }^{15}$

Pemberian diet Mediteranian, dimana asam lemak tidak jenuh majemuk (polyunsaturated fatty acid) diganti dengan asam lemak tidak jenuh tunggal (monounsaturated fatty acid), terbukti dapat menurunkan mortalitas pada komunitas lanjut usia di Eropa sebesar $7 \%{ }^{16}$

Sterol dan stanol ester yang berasal dari tumbuhan, dapat menghambat penyerapan kolesterol di intestinal yang berasal dari makanan dan dari empedu. Dalam masyarakat umum dan pada penyandang diabetes tipe 2, asupan $\pm 2 \mathrm{~g} /$ hari sterol dan stanol telah terbukti dapat menurunkan kadar 
kolesterol total plasma dan kolesterol LDL. ${ }^{17}$

\section{Pengaturan protein}

Asupan protein bagi penyandang diabetes adalah sama dengan masyarakat umumnya dan biasanya tidak melebihi $20 \%$ dari asupan energi total. Kualitas sumber protein yang baik adalah sumber protein yang mengandung asam-asam amino esensial yang lengkap yakni mencakup sembilan jenis asam amino esensial. ${ }^{2,18}$

Diet tinggi protein tidak direkomendasikan sebagai metode untuk menurunkan berat badan pada penyandang diabetes, sebab efek jangka panjang serta komplikasi dari asupan protein melebihi $20 \%$ dari kalori total harian masih belum diketahui pasti. Penerapan diet tinggi protein yang dikombinasikan dengan latihan ketahanan (resistance training) dapat menghasilkan penurunan berat badan, perbaikan profil glukosa darah, lingkar pinggang dan penanda risiko kardiovaskuler lainnya, namun apakah keadaan tersebut akan tetap berlanjut dalam jangka panjang serta efek samping pada fungsi ginjal masih belum diketahui. $^{19}$

\section{Rekomendasi nutrisi untuk pengendalian komplikasi diabetes (pencegahan diabetes tersier)}

\section{Komplikasi mikrovaskuler}

Perkembangan komplikasi dari diabetes dapat dihambat dengan memperbaiki kontrol glukosa darah, menurunkan tekanan darah, dan mengurangi asupan protein. ${ }^{21}$ Asupan protein normal $(15-20 \%$ dari kalori total) tidak berhubungan dengan risiko berkembangnya suatu nefropati diabetes, juga efek jangka panjang terhadap terjadinya nefropati akibat asupan protein diet yang lebih dari $20 \%$ masih belum dapat dipastikan. ${ }^{20}$

Pada penyandang diabetes yang telah mengalami mikro-albuminuria, pengurangan asupan protein telah terbukti meningkatkan laju filtrasi glomerulus. dan dapat mengurangi ekskresi albumin urin. Pembatasan asupan protein sejumlah $0,8 \mathrm{gr} / \mathrm{kg}$ berat badan/hari pada penyandang diabetes dengan makroalbuminuria menunjukkan adanya perlambatan dari penurunan laju filtrasi glo- merular. ${ }^{20}$ Pembatasan asupan protein haruslah mempertimbangkan kebutuhan untuk mempertahankan status gizi yang baik pada individu dengan gagal ginjal kronis. Pada beberapa studi menunjukkan bahwa pemberian protein nabati lebih baik dibandingkan protein hewani pada individu dengan gagal ginjal. $^{21}$

\section{Penanganan risiko penyakit kardiovaskuler}

Berdasarkan studi observasional dari The United Kingdom Prospective Diabetes Study (UKPDS) peningkatan risiko penyakit kardiovaskuler sebanding dengan pening-katan kadar HbA1c, sehingga direkomen-dasikan untuk mempertahankan kadar HbA1c senormal mungkin tanpa komplikasi hipoglikemia yang berarti. ${ }^{22}$

Hipertensi merupakan salah satu prediktor adanya perburukan dari komplikasi mikro dan makrovaskuler dari diabetes, sehingga hal ini dapat dicegah dan diatasi dengan penurunan berat badan, aktivitas fisik teratur, mengurangi konsumsi alkohol, dan pengaturan diet. ${ }^{23}$ Dianjurkan diet yang kaya dengan buah-buahan, sayuran, dan produk susu rendah lemak, termasuk biji-bijian utuh, ikan dan kacang-kacangan serta mengurangi lemak yang berasal dari daging yang berwarna merah, permen, dan minuman yang mengandung gula. ${ }^{23}$ Terapi gizi medis untuk pengelolaan hipertensi berfokus pada penurunan berat badan dan mengurangi asupan natrium sebab pengurangan asupan natrium akan berefek pada penurunan tekanan darah dan efek yang sama juga didapatkan pada penurunan berat badan. Beberapa studi metaanalisis menjelaskan hubungan antara asupan natrium dan tekanan darah dimana dengan pembatasan sedang natrium (sodium 2.400 $\mathrm{mg} /$ hari $(100 \mathrm{mmol})$ atau natrium klorida (garam dapur) $6.000 \mathrm{mg} / \mathrm{hari}$ ) dapat menurunkan tekanan darah sebanyak $\pm 5 \mathrm{mmHg}$ untuk sistolik dan $\pm 2 \mathrm{mmHg}$ untuk tekanan darah diastolik pada subyek hipertensi dan pengurangan dari $\pm 3 \mathrm{mmHg}$ untuk sistolik dan $\pm 1 \mathrm{mmHg}$ untuk tekanan darah diastolik pada subyek normal. ${ }^{24}$

Terapi gizi medis pada penyandang diabetes dengan dislipidemia adalah dengan 
membatasi konsumsi asam lemak jenuh dan asam lemak trans $<7 \%$ dari total kalori, dan asupan kolesterol $<200 \mathrm{mg} /$ hari, meningkatkan konsumsi serat terlarut (soluble fibre) sejumlah 10-25 gr/hari, stanol/sterol dari tumbuhan $2 \mathrm{gr} / \mathrm{hr}$, menurunkan berat badan dan melakukan aktivitas fisik. Pemberian suplementasi dengan minyak ikan yang mengandung asam lemak omega-3 dapat direkomendasikan. ${ }^{4,15}$

\section{Rekomendasi nutrisi pada penyandang diabetes dengan komplikasi akut dan pada pasien diabetes dengan keadaan khusus.}

\section{Hipoglikemia}

Pada penyandang diabetes yang menggunakan insulin atau insulin sekretagog, adanya perubahan pada aktivitas fisik atau perubahan pada asupan makanan dapat menyebabkan keadaan hipoglikemia (glukosa plasma $<70 \mathrm{mg} / \mathrm{dL}$ ) sehingga dibutuhkan asupan glukosa atau makanan yang mengandung glukosa.,25

Untuk hipoglikemia yang disebabkan pemberian insulin, 10 gr glukosa oral dapat meningkatkan kadar glukosa plasma \pm 40 $\mathrm{mg} / \mathrm{dL}$ selama 30 menit, sedangkan $20 \mathrm{gr}$ glukosa oral dapat meningkatkan kadar glukosa plasma $\pm 60 \mathrm{mg} / \mathrm{dL}$ selama 45 menit. Biasanya kadar glukosa plasma akan menurun \pm 60 menit setelah pemberian glukosa, sehingga untuk keadaan hipoglikemia kadar glukosa plasma harus diperiksa pada 60 menit sesudah pemberian glukosa. Penambahan protein atau lemak tidak mempengaruhi respon glisemik dan tidak mencegah hipoglikemia berulang. ${ }^{26}$

\section{Keadaan penyakit akut}

Keadaan penyakit akut dapat mencetuskan hiperglikemia juga ketoasidosis sehingga diperlukan monitoring kadar glukosa plasma dan keton, pemberian cairan yang adekuat, pemberian insulin atau obat-obatan penurun kadar glukosa serta asupan karbohidrat. Pada orang dewasa, pemberian 150-200 gr karbohidrat per hari (45-50 gr setiap $3-4$ jam) adalah cukup untuk mencegah ketosis akibat kekurangan asupan kalori. ${ }^{27}$

\section{Penyandang diabetes dalam fasilitas pera- watan medis}

Hiperglikemia pada pasien dalam perawatan medis adalah hal yang sering terjadi. Keadaan ini merupakan salah satu faktor prognostik buruk yang dihubungkan dengan mortalitas pada pasien dengan atau tanpa diabetes sehingga dengan mengoptimalkan kontrol glukosa akan memberikan prognosis yang lebih baik. ${ }^{28}$

Kebutuhan kalori harian pada pasien dalam perawatan medis adalah $25-30 \mathrm{kkal} / \mathrm{kg}$ berat badan per hari, atau \pm 200 gr karbohidrat per hari yang dibagi seimbang antara makanan pokok dan makanan selingan. Untuk pemberian makanan melalui pipa lambung, jenis formula standar yang mengandung 50\% karbohidrat dapat digunakan. Untuk pasien pasca bedah, makanan haruslah diberikan sesegera mungkin setelah dapat ditolerir. $^{27}$

\section{Pasien diabetes dengan kehamilan dan laktasi}

Pada penyandang diabetes dengan kehamilan, pengaturan energi dan asupan karbohidrat adalah berdasarkan respons glukosa plasma dengan tetap mempertimbangkan kebiasaan makan pasien. Seiring dengan perkembangan janin, maka glukosa secara terusmenerus akan diambil dari ibu, sehingga perlu adanya pengaturan pola makan ibu yang mencakup konsistensi waktu makan serta jumlah asupan makanan untuk mencegah risiko hipoglikemia. ${ }^{29}$ Pencatatan mengenai jumlah dan jenis makanan, serta kadar gula darah harian akan memberikan informasi berharga dalam menentukan pemberian insulin dan penyesuaian terhadap perencanaan diet. $^{28}$

Terapi gizi medis pada penyandang diabetes melitus gestasional harus dilaksanakan saat pertama kali didiagnosis. Pemberian terapi insulin diperlukan dalam mengontrol kadar glukosa plasma, serta untuk mengurangi risiko komplikasi perinatal. ${ }^{28}$

Diet rendah kalori pada kehamilan yang obes dengan diabetes melitus gestasional dapat menyebabkan ketonemia dan ketonuria. Akan tetapi, dengan pembatasan kalori 
sedang (30\% dari total kebutuhan energi) dapat memperbaiki kontrol glukosa serta menurunkan pertambahan berat badan tanpa menyebabkan ketonemia. ${ }^{28}$

Jumlah karbohidrat yang digunakan adalah dengan mempertimbangkan kadar glukosa plasma, rasa lapar, pertambahan berat badan, dan kadar keton. Pengaturan diet dapat dibagi dalam tiga porsi makanan pokok dalam jumlah kecil hingga sedang, beserta makanan selingan sebanyak dua sampai empat kali per hari. Pemberian makanan selingan pada malam hari dibutuhkan untuk mencegah ketosis pada malam hari. ${ }^{28}$

Pada ibu laktasi dengan diabetes, biasanya kebutuhan insulin harian lebih rendah dari biasanya, hal ini disebabkan karena sejumlah kalori yang harus digunakan untuk menyusui dan merawat bayi. Pada ibu dengan laktasi sering ditemui adanya fluktuasi pada kadar glukosa darah, hal ini berhubungan dengan waktu merawat bayi, sehinga dibutuhkan makanan selingan yang mengandung karbohidrat sebelum atau sementara menyusui. $^{29}$

\section{Penyandang diabetes lanjut usia}

Penatalaksanaan terapi gizi medis pada penyandang diabetes yang lanjut usia (lansia) membutuhkan perhatian khusus. Pembatasan asupan makanan pada individu lansia tidak dianjurkan mengingat bahaya terjadinya malnutrisi dan dehidrasi, sehingga untuk kontrol gula darah lebih difokuskan pada terapi farmakologis. Menurunkan berat badan pada penyandang diabetes lansia dengan berat badan lebih harus dievaluasi secara hati-hati. Suplementasi dengan multivitamin harian dapat diberikan, khususnya pada individu dengan asupan gizi yang kurang. ${ }^{30}$

Dari uraian di atas jelaslah bahwa pemberian TGM pada penyandang diabetes sangat bersifat individual, tergantung pada individu tersebut, keadaan diabetesnya, serta komplikasi dan keadaan khusus yang menyertainya. Pemahaman yang baik mengenai TGM akan sangat membantu penyandang diabetes untuk mencapai tingkat kesehatan yang optimal.

\section{KESIMPULAN}

Terapi gizi medis (TGM) adalah terapi gizi yang meliputi terapi diagnostik, dan manajemen penyakit termasuk layanan konseling, yang diberikan oleh seorang ahli diet terdaftar (registered dietitian) atau seorang ahli gizi profesional (nutrition professional).

Pada individu prediabetes atau diabetes, TGM sangat berperan dalam pencegahan perkembangan diabetes dan komplikasinya, serta pengelolaan penyandang diabetes dengan tetap mempertimbangkan preferensi pribadi atau kebiasaan budaya setempat serta mempertahankan kenikmatan dalam mengkonsumsi makanan. Keseimbangan energi dan berat badan, konposisi makro serta mikronutrien perlu dicermati dengan baik, terlebih lagi pada penyandang diabetes dengan komorbidnya.

\section{DAFTAR PUSTAKA}

1. Morris SF, Wylie-Rosett J. Medical nutrition therapy: A key to diabetes management and prevention. Clinical diabetes. 2010;28:1-18.

2. McGough N. Nutritional recomendation in diabetes management. In: Frost G, Dornhorst A, Moses R. Nutritional management of diabetes mellitus. England: John Willey and Sons, The Atrium, West Sussex, 2007; p 1-15.

3. Pastors JG, Warshaw H, Daly A, Franz M, Kulkarni K. The evidence for the effectiveness of medical nutrition therapy in diabetes management. Diabetes Care. 2002;25:608-13.

4. Bantle JP, Wylie-Rosett J, Albright A, Apovian CM, Clark NG, Franz MJ, et al. Nutrition recommendations and interventions for diabetes: a position statement of the American Diabetes Association. Diabetes Care. 2008;31:S61-S78.

5. The National Heart, Lung, and Blood Institute: Clinical guidelines on the identification, evaluation and treatment of overweight and obesity in adults. Bethesda MD: National Institutes of Health, 1998.

6. Holt SHA, Miller JC. The role of carbohydrate in management of diabetes. In : Frost G, Dornhorst A, Moses R. Nutritional management of diabetes mellitus. 
London UK: Willey, 2007; p: 177.

7. Brand-Miller J, Hayne S, Petocz $\mathbf{P}$, Colagiuri S. Low-glycemic index diets in the management of diabetes: a metaanalysis of randomized controlled trials. Diabetes Care. 2003;26:2261-7.

8. American Diabetes Association: Nutrition principles and recommendations in diabetes for the treatment and prevention of diabetes and related complications (Position Statement). Diabetes Care. 2004;26:S36-46.

9. Hasanain B, Mooradian AD. Antioxidant vitamins and their influence in diabetes mellitus. Curr Diab Rep. 2002;2:448-56.

10.Lonn E, Yusuf S, Hoogwerf B, Pogue J, Yi Q, Zinman B, et al. Effects of vitamin E on cardiovascular and microvascular outcomes in high-risk patients with diabetes: results of the HOPE study and MICROHOPE substudy. Diabetes Care. 2002;25:1919-27.

11.Brand-Miller JC, Stockmann K, Atkinson F. Glycemic index, postprandial glycemia and the shape of the curve in healthy subjects: analysis of a database of more than 1000 foods. Am J Clin Nutr. 2009;89:97-105.

12.Liese AD, Schulz M, Fang F, Wolever TM, D'Agostino RB Jr, Sparks KC, et al. Dietary glycemic index and glycemic load, carbohydrate and fiber intake, and measures of insulin sensitivity, secretion, and adiposity in the Insulin Resistance Atherosclerosis Study. Diabetes Care. 2005;28:2832-8.

13.Koppes LL, Dekker JM, Hendriks HF, Bouter LM, Heine RJ. Moderate alcohol consumption lowers the risk of type 2 diabetes: a meta-analysis of prospective observational studies. Diabetes Care. 2005;28:719-25.

14. Raben A, Vasilaras TH, Moller AC, Astrup A. Sucrose compared with artificial sweeteners: different effects on ad libitum food intake and body weight after 10 wk of supplementation in overweight subjects. Am J Clin Nutr. 2002;76:721-9.

15.Kris-Etherton PM, Harris WS, Appel LJ. Fish consumption, fish oil, omega-3 fatty acids, and cardiovascular disease. Circulation. 2002;106:2747-57.

16. Trichopoulou A, Orfanos P, Norat T. Modified Mediterranean diet and survival: EPIC-elderly prospective cohort study.
BMJ. 2005;330:991.

17.Lee YM, Haastert B, Scherbaum W, Hauner H. A phytosterol-enriched spread improves the lipid profile of subjects with type 2 diabetes mellitus: a randomized controlled trial under freeliving conditions. Eur $\mathrm{J}$ Nutr. 2003;42:111-7.

18.Gannon MC, Nuttall FQ. Effect of a highprotein, low-carbohydrate diet on blood glucose control in people with type 2 diabetes. Diabetes. 2004;53:2375-82.

19.Wycherley TP, Noakes M, Clifton PM. A high protein diet with resistance exercise training improves weight loss and body composition in overweight and obese patients with type 2 diabetes. Diabetes Care. 2010;33:969-76.

20.Narita T, Koshimura J, Meguro H, Kitazato H, Fujita H, Ito S. Determination of optimal protein contents for a protein restriction diet in type 2 diabetic patients with microalbuminuria. Tohoku J Exp Med. 2001;193:45-55.

21.Hansen HP, Tauber-Lassen E, Jensen BR, Parving HH. Effect of dietary protein restriction on prognosis in patients with diabeticnephropathy. Kidney Int. 2002; 62:220-8.

22.Stratton IM, Adler AI, Neil HA, Matthews DR, Manley SE, Cull CA, et al. Association of glycaemia with macrovascular and microvascular complications of type 2 diabetes (UKPDS 35): prospective observational study. BMJ. 2000;321:40512.

23.Appel LJ, Brands MW, Daniels SR, Karanja N, Elmer PJ, Sacks FM. Dietary approaches to prevent and treat hypertension: a scientific statement from the American Heart Association. Hypertension. 2006;47:296-308.

24.Sacks FM, Svetkey LP, Vollmer WM. The DASH-Sodium Collaborative Research Group: Effects on blood pressure of reduced dietary sodium and the dietary approaches to stop hypertension (DASH) diet. N Engl J Med. 2001;344:3-10.

25.Hunt SA, Abraham WT, Chin MH. ACC/AHA 2005 Guideline update for the diagnosis and management of chronic heart failure in the adult-summary article. Circulation. 2005;112:1825-52.

26. Cryer PE, Davis SN, Shamoon H. Hypoglycemia in diabetes. Diabetes 
Care. 2003;26:1902-12.

27.American Diabetes Association: Diabetes nutrition recommendations for health care institutions (Position Statement). Diabetes Care. 2004;27:S55-7.

28. Crowther CA, Hiller JE, Moss JR. Effect of treatment of gestational diabetes mellitus on pregnancy outcomes. N Engl J Med. 2005;352:2477-86.
29.Reader D, Franz MJ. Lactation, diabetes, and nutrition recommendations. Curr Diab Rep. 2004;4:370-6.

30.Brown AF, Mangione CM, Saliba D, Sarkisian CA. Guidelines for improving the care of the older person with diabetes mellitus. J Am Geriatr Soc. 2003;51:S265-80. 